\title{
Assessment of Waste Management in Healthcare Industry by using DEMATEL Technique
}

\author{
R.K.A.Bhalaji, S. Bathrinath, S. Saravanasankar
}

\begin{abstract}
Healthcare waste management is the major task for the industry especially in rising nations like India. It is problematic to identify and control the wastes has turn out to be one of the serious concerns. For the assessment of waste management, case study is conducted in one of the top healthcare industry in India. The objective of the paper is to identify and assess the most influential wastes in the healthcare industry. In this paper, ten wastes are recognized from relevant literature and used to recognize the most influential wastes in the healthcare industry by using Decision Making Trail and Evaluation Laboratory (DEMATEL) technique. This technique evaluates the importance of wastes and also displays its causal relations. The finding of the paper reveals that wastes from genotoxic chemical (W8) is the most influential waste in the healthcare industry and needs to be control it.
\end{abstract}

Keywords: DEMATEL, Healthcare, India.

\section{INTRODUCTION}

$\mathrm{R}$ ising nations like India faces waste management problem in the healthcare industry for the past few years, it affects the environment as well as the workers and public health. At the time of managing and disposal of healthcare waste management activity such as improper and poor management that leads to environmental pollution and health hazards because of its hazardous environment [1]. During the time of human beings treatment in the hospitals, it generates liquid and solid waste form research in medical, testing and pathological and medical diagnosis (WHO 2002). Chemical wastes, wastes from metals, genotoxic substances in the healthcare industry are the most harmful one in the process. If not managed properly, it will affect the environment and employees ill-health [2]. It is a major task for every industry in India, they difficult to control the waste in the industry. To overcome this issue, we used the DEMATEL method for analysing the wastes in the healthcare industry. The outcomes of the paper will help the managers and practitioners for implementing the waste management system as well as controlling the wastes.

Revised Manuscript Received on December 05, 2019.

* Correspondence Author

R.K.A.Bhalaji, Department of mechancical engineering, Kalasalingam Academy of research and education, Krishnankoil-626126, India. Email: bhalaji28@gmail.com

S.Bathrinath*, Department of mechancical engineering, Kalasalingam Academy of research and education, Krishnankoil-626126, India. Email: bathri@gmail.com

S.Saravanasankar, Department of mechancical engineering, Kalasalingam Academy of research and education, Krishnankoil-626126, India. Email: ssaravanasankar@klu.ac.in

\section{RELEVANT LITERATURE}

The relevant literature is sorted into three sub-segments namely (A) To identify the waste in healthcare industry (B) To identify the waste in healthcare industry by using MCDM methods (C) Literature Gap

\section{A. To identify the waste in healthcare industry}

Abah and Ohimain [3] evaluating the waste management in Nigerian healthcare industry. The findings of the study showed that $90 \%$ waste occurred in in-patient wards and $70 \%$ waste occurred in out-patient wards and they suggest some control measures such as implementing a control plan for healthcare waste, proper training for employees and create awareness about waste for both workers as well as visitors. Manga et al. [4] assessing the waste in Cameroon healthcare industry. The result shows that waste from medicines is the most influential one in the industry and they suggest proper rules and regulations for disposal and managing the wastes from medicines. Patwary et al. [5] analysed the waste from medicines in a five healthcare industries from Dhaka. The consequences of the study demonstrated that segregation of waste is the major impact problem in the industry and it leads to more hazardous for mixing with other wastes. Alam et al. [6] surveyed the waste management in healthcare industry from Aligarh. Based on the survey and analysis, approximately $700-800 \mathrm{~kg}$ of waste created per day and they need safe and proper disposal and plan for waste management.

\section{B. To identify the waste in healthcare industry by using MCDM}

Ciplak [7] recognize the best one in the waste management system of Turkish healthcare industry by using MCDM technique. The findings of the study displaying that landfilling disposal with the recovery of energy is the best one in the system and they give special care to segregation of waste. Dursun et al. [8] analysed the alternatives of waste management in Turkish healthcare industry by using Fuzzy based MCDM. The results showed that sterilization of steam is the critical one in the industry. Liu et al. [9] examined the best alternative in the waste management system in the healthcare industry from china by using Fuzzy multi-moora method. From the above study, the consequences displayed that landfill is the best alternative in the system. Aung et al. [10] reviewed the waste management in Myanmar healthcare industry by using

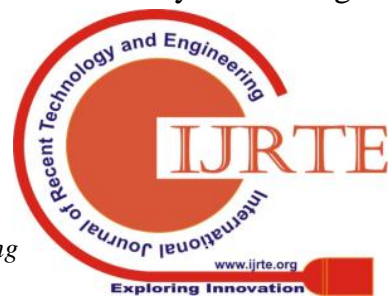


MCDM method. Set of rules and regulations for waste management system, technologies for controlling waste and skill of experts are required for the waste management system for reducing waste.

\section{Literature gap}

As of now, there is no research paper related to assessment of waste management in the healthcare industry by using DEMATEL method based on the existing literatures. In order to fulfill this gap, this paper analyses the waste management in healthcare industry by using DEMATEL method. The findings of this paper will surely help the mangers for implementing the waste management system as well as reducing the severity of wastes.

Table- I: Categories of wastes

\begin{tabular}{|c|c|c|}
\hline S.No & Waste & Notation \\
\hline 1 & Wastes from pharmaceutical products & W1 \\
\hline 2 & Wastes from hazardous chemicals & W2 \\
\hline 3 & Wastes from chemical substances & W3 \\
\hline 4 & Waste from medicines & W4 \\
\hline 5 & Waste from radioactive substances & W5 \\
\hline 6 & Waste from tissues & W6 \\
\hline 7 & Municipal wastes & W7 \\
\hline 8 & Waste from Genotoxic substances & W8 \\
\hline 9 & Waste from high content of heavy & W9 \\
\hline 10 & Pressurized containers & W10 \\
\hline
\end{tabular}

\section{FRAMEWORK OF THE PAPER}

The framework of the paper is presented in Figure 1.

\section{PROPOSED METHODOLOGY}

In this paper, the aim is to analyze the waste in healthcare industry by using DEMATEL method.

\section{A. DEMATEL}

It is a method to examine the relationship between each and every factors and it is a conventional method to solve any complicated issues in industries [11]. DEMATEL method procedures are described in detail below [12-13].

Step 1: Computation of initial direct relation matrix ' $D$ '

To compare and examine the wastes on the basis of inputs from decision makers for constructing the ' $D$ ' matrix. The mathematical formulation for ' $\mathrm{D}$ ' matrix is given below.

$$
D=\left[\begin{array}{cccccc}
1 & D_{12} & D_{13} & \Lambda & D_{1(n-1)} & D_{1 n} \\
D_{21} & 1 & D_{23} & \Lambda & D_{2(n-1)} & D_{2 n} \\
\Lambda & \Lambda & \Lambda & \Lambda & \Lambda & \Lambda \\
\Lambda & \Lambda & \Lambda & \Lambda & \Lambda & \Lambda \\
D_{(n-1) 1} & D_{(n-1) 2} & D_{(n-2) 3} & \Lambda & 1 & D_{(n-1) 1} \\
D_{n 1} & D_{n 2} & D_{n 3} & \Lambda & D_{n(n-1)} & 1
\end{array}\right](1)
$$

The scale used for the method is shown in Table 2.

Table- II: LINGUISTIC SCALE

\begin{tabular}{|c|c|}
\hline Mutable & Impact score \\
\hline No impact & 0 \\
\hline Very low impact & 1 \\
\hline Low impact & 2 \\
\hline High impact & 3 \\
\hline Very high impact & 4 \\
\hline
\end{tabular}

Inputs are gathered from decision makers and they give rating for wastes by using questionnaire.

Step 2: Normalizing the 'D' matrix (N)

$$
\begin{aligned}
& M=\frac{1}{\max _{1 \leq i \leq n}} \sum_{j=1}^{n} D_{i j} \\
& N=M \times D
\end{aligned}
$$

Step 3: Computation of Total relation matrix ' $\mathrm{T}$ '

$$
T=N(I-N)^{-1}
$$

Step 4: Computation of summation of rows and columns Summation of rows and columns are computed by using equations (5) and (6) and signified as $r o_{i}$ and $\mathrm{CO}_{i}$ correspondingly.

$$
\begin{aligned}
r o_{i} & =\left[\sum_{j=1}^{n} D_{i j}\right]_{n \times 1} \\
c o_{i} & =\left[\sum_{i=1}^{n} D_{i j}\right]_{1 \times n}
\end{aligned}
$$

Step 5: Causal diagram

Using $\mathrm{ro}_{i}$ and $\mathrm{CO}_{i}$ value, the causal diagram is generated. Both horizontal and vertical axis of the graph is mapped by using $\left(\mathrm{rO}_{i}+\mathrm{CO}_{i}\right)$ and $\left(\mathrm{ro}_{i}-\mathrm{Co}_{i}\right)$ values. The causal diagram shows the most critical waste in the healthcare industry and defines the relationship between each waste.

\section{CASE STUDY}

The suggested method used for analyzing the wastes in healthcare industry. As per the reports gathered from the industries, they face waste management problem for the past 10 years. It affects the environment as well as the health of all employees. The case industry is the leading one in the southern region of India with the annual turnover of 50 crores of Indian rupees. More than 600 employees are worked in the industry. It is essential to analyze the wastes in the industry for the effective implementation of waste management. The outcomes of the paper will surely help the managers to understand what are the wastes involved in the 
industry and how to reduce it and also used for implementation of waste management system.

\section{RESULT AND DISCUSSIONS}

In this paper, to identify the critical waste in the healthcare industry by using DEMATEL method. In the routine life, waste management in the healthcare industry is the problematic one to control. This paper explores ten wastes in the healthcare industry and their interrelationships with every waste are analyzed by using DEMATEL method. This study was conducted based on the causal diagram and depicted in Fig 1.

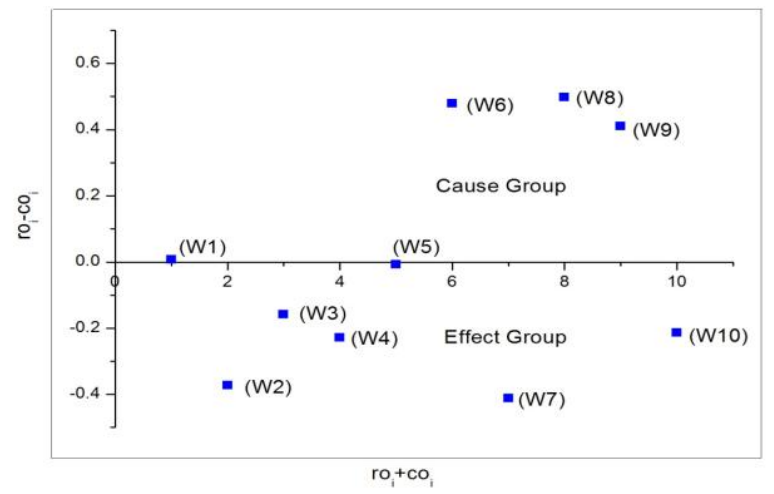

Fig. 2. Causal diagram

From the Table 7, the sequence of order of ten wastes in the healthcare industry through a prominence vector is stated as W7-W4-W3-W2-W1-W8-W9-W5-W6-W10. Based on the $\left(r o_{i}+\mathrm{Co}_{i}\right)$, municipal wastes (W7), wastes from medicines (W4) and wastes from chemical substances (W3) are the critical wastes in the healthcare industry with the values of $4.539,3.495$ and 3.477 correspondingly. Wastes form radioactive substances (W5), wastes from tissues (W6) and pressurized containers (W10) are the uncritical one in the healthcare industry with the values of $2.603,2.533$ and 1.558 respectively.

Table- III: Initial DRM

\begin{tabular}{|l|l|l|l|l|l|l|l|l|l|l|}
\hline & W1 & W2 & W3 & W4 & W5 & W6 & W7 & W8 & W9 & W10 \\
\hline W1 & 0 & 2 & 2 & 3 & 1 & 1 & 4 & 1 & 1 & 0 \\
\hline W2 & 1 & 0 & 3 & 2 & 2 & 0 & 3 & 1 & 1 & 1 \\
\hline W3 & 2 & 3 & 0 & 2 & 1 & 2 & 3 & 1 & 1 & 0 \\
\hline W4 & 3 & 2 & 2 & 0 & 1 & 1 & 3 & 1 & 1 & 1 \\
\hline W5 & 2 & 2 & 1 & 1 & 0 & 1 & 2 & 1 & 1 & 1 \\
\hline W6 & 1 & 2 & 2 & 2 & 1 & 0 & 2 & 2 & 1 & 1 \\
\hline W7 & 3 & 2 & 2 & 3 & 2 & 2 & 0 & 2 & 2 & 2 \\
\hline W8 & 1 & 3 & 3 & 2 & 1 & 1 & 2 & 0 & 1 & 1 \\
\hline W9 & 1 & 1 & 2 & 2 & 2 & 1 & 3 & 1 & 0 & 1 \\
\hline W10 & 1 & 1 & 0 & 0 & 1 & 0 & 2 & 0 & 1 & 0 \\
\hline
\end{tabular}

Based on the relative vector $\left(\mathrm{ro}_{i}-\mathrm{Co}_{i}\right)$ in Table 8, wastes from genotoxic substances (W8), waste from tissues (W6), waste from high content on heavy metals (W9) and wastes from pharmaceutical products (W1) are sorted into cause group and municipal wastes (W7), waste from hazardous chemicals (W2), waste from medicines (W4), pressurized containers (W10), waste from chemical substances (W3) and waste from radioactive substances (W5) are sorted into effect group.

\section{A. Discussion of wastes in the cause group}

All wastes in the cause group are the vital one, it is difficult to focus various wastes between them. In the cause group, waste from genotoxic substances (W8) has a $\left(\mathrm{ro}_{i}-\mathrm{CO}_{i}\right)$ value of 4.539 , shows that W8 has a maximum influence between other wastes. But the $\left(\mathrm{ro}_{i}+\mathrm{Co}_{i}\right)$ value is 2.720 which is in the medium range and shows low influence. Genotoxic waste in the healthcare industry comes from drugs used in cancer therapy and they have highly hazardous it leads to safety related problems for all employees. Therefore, i suggest safe disposal and appropriate treatment is required for the industry to control genotoxic waste and also need special attention for this waste. The second most essential one is waste from tissues (W6) has a $\left(\mathrm{rO}_{i}-\mathrm{CO}_{i}\right)$ value of 3.495 with the equivalent $\left(\mathrm{rO}_{i}+\mathrm{CO}_{i}\right)$ value of 2.533. It is mainly occurring due to body parts or organs are removed at the time of surgery and they can be generated in mortuaries, operating theatres etc. It is deliberated as an infectious waste for preventive reasons. Therefore the proper storage room is important for body organs in the industry. Waste from high content of heavy metals (W9) with a $\left(\mathrm{ro}_{i}-\mathrm{CO}_{i}\right)$ value of 3.477. From the thermometers and manometers, both mercury and cadmium plays a major role and it tends to be highly contaminated. Concerned authorities should be treated specially with the correct procedure. The last one in the cause group is wastes from pharmaceutical products with a $\left(\mathrm{rO}_{i}-\mathrm{CO}_{i}\right)$ value of 3.416. Expired, unused and highly toxic products and vaccines in the industry affect the environment as well as workers ill-health. As per the rules and regulations of ministry of health and welfare, industry should take precautionary steps to control and minimize the drugs wastage.

\section{B. Discussion of wastes in the effect group}

In the effect group, the most influential one is municipal wastes (W7) with a $\left(\mathrm{ro}_{i}-\mathrm{Co}_{i}\right)$ value of -0.412 . Packaging wastes is the primary one in the municipal wastes it comes from reusable and recyclable wastes from warehouses, offices and kitchen etc. and general wastes is the secondary one it comes from wards for both inpatients and outpatients, operating rooms and first aid sections etc. For overcoming this issue, proper housekeeping is needed for every hour and it should be checked by official supervisors. The second one in the effect group are waste from hazardous chemicals (W2) has a $\left(\mathrm{rO}_{i}-\mathrm{CO}_{i}\right)$ value of -0.373 . During the process of cleaning, discarded chemicals are in the solid, liquid and gaseous form are generated and it tends to be highly flammable, corrosive and contaminated. As per the specification mentioned in the chemical container, the chemical should be used and disposed. The order of sequence of other wastes in the effect group are waste from medicines 
pressurized containers (W10), wastes from chemical substances (W3) and also the wastes from radioactive substances (W5) with a $\left(\mathrm{ro}_{i}-\mathrm{Co}_{i}\right)$ value of $-0.228,-0.213$, -0.158 and -0.008 . In the radioactive waste, cobalt, iodine and iridium are the critical materials and used in the imaging and therapeutic investigation. It spills and affects the environment. Here, permanent warehouses are needed with suitable retention time is enough to control wastage in radioactivity and to prevent from environment spillage.

\section{CONCLUSION}

In the entire world, it is understood that all healthcare organizations faces waste management problem and they need preventive care to waste management. Due to the time restriction, they always use some conventional methods for analyzing waste management in the industry but it is a complicated task to handle it. To overcome this issue, DEMATEL method is used to analyse the waste management in the healthcare industry. By using this method, it is easy to analyze interrelationship between wastes and to recognizes the critical waste in the healthcare industry as well as handles complicated problems. In this paper, wastes from genotoxic substances (W8) plays a major role between other wastes in the healthcare industry based on Fig 1. Proper treatment and safe disposal is essential to control waste from genotoxic substances. The findings of the paper will surely help the mangers and practitioners to improve their waste management in the healthcare industry and also satisfy the both employers and employees. For the future perspective, this paper has some limitations that can be investigated later. For this instance, analysis of waste management is deliberated on one wastes influence over other wastes and some wastes may not have good relationship with other wastes. In this paper, these features are not deliberated. To solve these limitations, some MCDM methods like ANP, TOPSIS and VIKOR may have good relationship features and also in this paper number of decision makers is limited. In future work, increasing the decision maker opinion for generate a structural model and to ensure the expansion of this work.

\section{REFERENCES}

1. H. C. Liu, J. X. You, C. Lu and Y. Z. Chen, "Evaluating health-care waste treatment technologies using a hybrid multi-criteria decision making model," Renewable and Sustainable Energy Reviews, Vol. 41, 2015, 932-942.

2. A. Z. Alagöz and G. Kocasoy, "Determination of the best appropriate management methods for the health-care wastes in Istanbul," Waste Management, Vol. 28(7), 2008, 1227-1235.

3. S. O. Abah and E. I. Ohimain, "Healthcare waste management in Nigeria: A case study," Journal of Public health and Epidemiology, Vol. 3(3), 2011, 99-110.

4. V. E. Manga, O. T. Forton, L. A. Mofor and R. Woodard, "Health care waste management in Cameroon: A case study from the Southwestern Region," Resources, Conservation and Recycling, Vol. 57, 2011, 108-116.

5. M. A. Patwary, W. T. O'Hare, G. Street, K. M. Elahi, S.S. Hossain and M. H. Sarker, "Quantitative assessment of medical waste generation in the capital city of Bangladesh," Waste management, Vol. 29(8), 2009, 2392-2397.
6. I. Alam, G. Alam, S. Ayub and A. A. Siddiqui, "Assessment of Bio-medical Waste Management in Different Hospitals in Aligarh City," In Advances in Waste Management (pp. 501-510). Springer, Singapore 2019.

7. N. Ciplak, "Assessing future scenarios for health care waste management using a multi-criteria decision analysis tool: A case study in the Turkish West Black Sea Region," Journal of the Air \& Waste Management Association, Vol. 65(8), 2015, 919-929.

8. M. Dursun, E. E. Karsak and M. A. Karadayi, "Assessment of health-care waste treatment alternatives using fuzzy multi-criteria decision making approaches," Resources, Conservation and Recycling, Vol. 57, 2011, 98-107.

9. H. C. Liu, J. X. You, C. Lu and M. M. Shan, "Application of interval 2-tuple linguistic MULTIMOORA method for health-care waste treatment technology evaluation and selection," Waste Management, Vol. 34(11), 2014, 2355-2364.

10. T. S. Aung, S. Luan and Q. Xu, "Application of multi-criteria-decision approach for the analysis of medical waste management systems in Myanmar," Journal of Cleaner Production, 2019.

11. R. K. A. Bhalaji, S. Bathrinath, S. G. Ponnambalam and S. Saravanasankar, "A Fuzzy Decision-Making Trial and Evaluation Laboratory approach to analyse risk factors related to environmental health and safety aspects in the healthcare industry," Sādhanā, Vol. 44(3), 2019, 55

12. S. Bathrinath, V. S. Charan, S. G. Ponnambalam and S Saravanasankar, "Identification and Evaluation of Criteria of Agile Manufacturing Using DEMATEL: A Case from an Indian Metal Fabrication Industry," Journal of Modern Manufacturing Systems and Technology, Vol. 2(1), 2019, 61-74

13. A. ALKAN, K. CANBAY, G. Akman and Z. ALADAĞ, "Researching Usage of GLOBE Culture Dimensions in Organizational Management by using DEMATEL Method," Sakarya University Journal of Science, Vol. 23(2), 2019, 1-1.

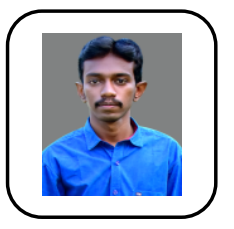

\section{AUTHORS PROFILE}

R.K.A.Bhalaji obtained his B.E (MECH) in 2014 from the K.L.N.College of Engineering, Madurai, Tamilnadu, India. He completed his M.Tech (Industrial Safety Engineering) in 2016 at the Kalasalingam Academy of Research and Education, Krishnankoil, Tamilnadu, India. Currently, he is a Research Scholar in the Department of Mechanical Engineering, Kalasalingam Academy of Research and Education, Krishnankoil, Tamilnadu, India. His research interests include multi-criteria decision making and application of fuzzy set theory in real life decision problems. He is currently pursuing PHD in the area of analysis of risk factors for the identification and evaluation for finding influential risk factors in healthcare industries by

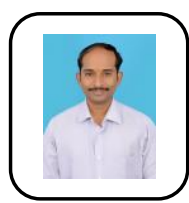
using MCDM methods.

Dr.S.Bathrinath is an Associate Professor in the Department of Mechanical Engineering, Kalasalingam Academy of Research and Education, Krishnankoil, Tamilnadu, India. His current area of research includes multi-criteria decision making, scheduling \& optimization, soft computing and Artificial intelligence. He has published a number of papers in journal of national/international repute and presented a number of papers in various conferences/symposia in India and abroad. He is presently guiding a number

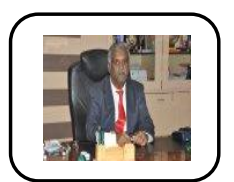
of master/doctoral research scholars. Dr.S.Bathrinath is the corresponding author and can be contacted at: bathri@gmail.com

Dr.S.Saravanasankar is a Senior Professor in the Department of Mechanical Engineering, Kalasalingam Academy of Research and Education, Krishnankoil, Tamilnadu, India. He has more than 20 years of experience in teaching and research. His current area of research includes scheduling, optimization and multi-criteria decision making. $\mathrm{He}$ has published more than 40 research articles in journals of national and international repute. 
International Journal of Recent Technology and Engineering (IJRTE) ISSN: 2277-3878, Volume-8 Issue-4S2, December 2019

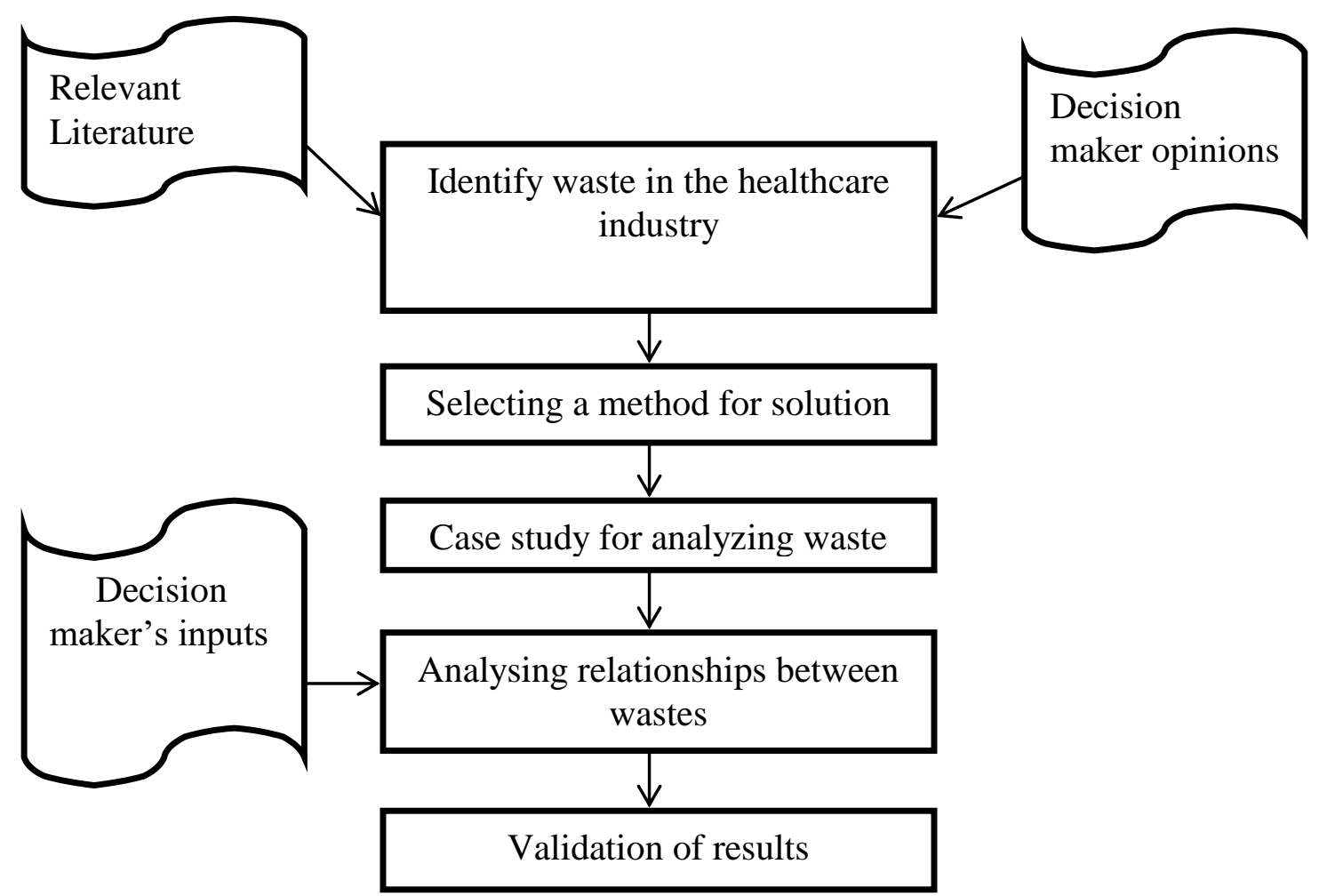

Fig. 1. FLOW DIAGRAM OF THE PAPER

Table- IV: Normalized DRM

\begin{tabular}{|c|c|c|c|c|c|c|c|c|c|c|}
\hline & W1 & W2 & W3 & W4 & W5 & W6 & W7 & W8 & W9 & W10 \\
\hline W1 & 0.000 & 0.083 & 0.083 & 0.125 & 0.042 & 0.042 & 0.167 & 0.042 & 0.042 & 0.000 \\
\hline W2 & 0.042 & 0.000 & 0.125 & 0.083 & 0.083 & 0.000 & 0.125 & 0.042 & 0.042 & 0.042 \\
\hline W3 & 0.083 & 0.125 & 0.000 & 0.083 & 0.042 & 0.083 & 0.125 & 0.042 & 0.042 & 0.000 \\
\hline W4 & 0.125 & 0.083 & 0.083 & 0.000 & 0.042 & 0.042 & 0.125 & 0.042 & 0.042 & 0.042 \\
\hline W5 & 0.083 & 0.083 & 0.042 & 0.042 & 0.000 & 0.042 & 0.083 & 0.042 & 0.042 & 0.042 \\
\hline W6 & 0.042 & 0.083 & 0.083 & 0.083 & 0.042 & 0.000 & 0.083 & 0.083 & 0.042 & 0.042 \\
\hline W7 & 0.125 & 0.083 & 0.083 & 0.125 & 0.083 & 0.083 & 0.000 & 0.083 & 0.083 & 0.083 \\
\hline W8 & 0.042 & 0.125 & 0.125 & 0.083 & 0.042 & 0.042 & 0.083 & 0.000 & 0.042 & 0.042 \\
\hline W9 & 0.042 & 0.042 & 0.083 & 0.083 & 0.083 & 0.042 & 0.125 & 0.042 & 0.000 & 0.042 \\
\hline W10 & 0.042 & 0.042 & 0.000 & 0.000 & 0.042 & 0.000 & 0.083 & 0.000 & 0.042 & 0.000 \\
\hline
\end{tabular}

Table- V: TRM

\begin{tabular}{|l|l|l|l|l|l|l|l|l|l|l|}
\hline & W1 & W2 & W3 & W4 & W5 & W6 & W7 & W8 & W9 & W10 \\
\hline W1 & 0.127 & 0.212 & 0.209 & 0.252 & 0.134 & 0.118 & 0.324 & 0.122 & 0.120 & 0.067 \\
\hline W2 & 0.154 & 0.122 & 0.228 & 0.197 & 0.161 & 0.072 & 0.270 & 0.111 & 0.112 & 0.096 \\
\hline W3 & 0.197 & 0.246 & 0.132 & 0.213 & 0.132 & 0.151 & 0.285 & 0.121 & 0.118 & 0.065 \\
\hline
\end{tabular}


Assessment of Waste Management in Healthcare Industry by using DEMATEL Technique

\begin{tabular}{|l|l|l|l|l|l|l|l|l|l|l|}
\hline W4 & 0.232 & 0.207 & 0.202 & 0.133 & 0.130 & 0.113 & 0.284 & 0.117 & 0.117 & 0.099 \\
\hline W5 & 0.169 & 0.179 & 0.139 & 0.143 & 0.072 & 0.095 & 0.211 & 0.101 & 0.100 & 0.088 \\
\hline W6 & 0.147 & 0.198 & 0.194 & 0.195 & 0.122 & 0.065 & 0.231 & 0.148 & 0.109 & 0.096 \\
\hline W7 & 0.258 & 0.239 & 0.233 & 0.273 & 0.187 & 0.165 & 0.214 & 0.172 & 0.171 & 0.151 \\
\hline W8 & 0.155 & 0.243 & 0.239 & 0.203 & 0.128 & 0.110 & 0.243 & 0.075 & 0.114 & 0.098 \\
\hline W9 & 0.152 & 0.160 & 0.190 & 0.196 & 0.161 & 0.109 & 0.267 & 0.112 & 0.071 & 0.098 \\
\hline W10 & 0.088 & 0.090 & 0.051 & 0.056 & 0.079 & 0.030 & 0.146 & 0.033 & 0.073 & 0.027 \\
\hline
\end{tabular}

Table- VI: Sum of influences given and received on criteria

\begin{tabular}{|l|l|l|l|l|}
\hline Wastes & $\mathrm{rO}_{\mathrm{i}}$ & $\mathrm{CO}_{\mathrm{i}}$ & $\mathrm{ro}_{\mathrm{i}}+\mathrm{CO}_{\mathrm{i}}$ & $\mathrm{rO}_{\mathrm{i}}-\mathrm{CO}_{\mathrm{i}}$ \\
\hline $\mathrm{W} 1$ & 1.685 & 1.678 & 3.363 & 0.007 \\
\hline $\mathrm{W} 2$ & 1.521 & 1.895 & 3.416 & -0.373 \\
\hline $\mathrm{W} 3$ & 1.659 & 1.817 & 3.477 & -0.158 \\
\hline W4 & 1.634 & 1.862 & 3.495 & -0.228 \\
\hline W5 & 1.297 & 1.306 & 2.603 & -0.008 \\
\hline W6 & 1.506 & 1.027 & 2.533 & 0.479 \\
\hline W7 & 2.063 & 1.111 & 4.539 & -0.412 \\
\hline W8 & 1.609 & 2.720 & 0.498 \\
\hline W9 & 1.515 & 2.621 & 0.410 \\
\hline W10 & 0.673 & 1.558 & -0.213 \\
\hline
\end{tabular}

Table- VII. PROMINENCE VECTOR $\left(\mathrm{ro}_{\mathrm{i}}+\mathrm{Co}_{\mathrm{i}}\right)$

\begin{tabular}{|l|l|l|}
\hline Rank & Wastes & $\mathrm{ro}_{\mathrm{i}}+\mathrm{co}_{\mathrm{i}}$ \\
\hline 1 & $\mathrm{~W} 7$ & 4.539 \\
\hline 2 & $\mathrm{~W} 4$ & 3.495 \\
\hline 3 & $\mathrm{~W} 3$ & 3.477 \\
\hline 4 & W2 & 3.416 \\
\hline 5 & W1 & 3.363 \\
\hline 6 & W8 & 2.720 \\
\hline 7 & W9 & 2.621 \\
\hline 8 & W5 & 2.603 \\
\hline 9 & W6 & 2.533 \\
\hline 10 & W10 & 1.558 \\
\hline
\end{tabular}

Table- VIII: RELATIVE VECTOR $\left(\mathrm{ro}_{\mathrm{i}}-\mathrm{co}_{\mathrm{i}}\right)$

\begin{tabular}{|l|l|l|}
\hline Rank & Cause group & $\mathrm{ro}_{i}-\mathrm{CO}_{i}$ \\
\hline 1 & W8 & 4.539 \\
\hline 2 & W6 & 3.495 \\
\hline 3 & W9 & 3.477 \\
\hline 4 & W1 & 3.416 \\
\hline Rank & Effect group & $\mathrm{ro}_{i}-\mathrm{CO}_{\mathrm{i}}$ \\
\hline 1 & W7 & -0.412 \\
\hline 2 & W2 & -0.373 \\
\hline 3 & W4 & -0.228 \\
\hline 4 & W10 & -0.213 \\
\hline 5 & W3 & -0.158 \\
\hline 6 & W5 & -0.008 \\
\hline
\end{tabular}

